\title{
The Role of Food in the Snowshoe Hare-Canada Lynx Cycle
}

\author{
by Yasmine Majchrzak
}

\section{INTRODUCTION}

$\mathrm{U}$ NDERSTANDING THE CAUSES BEHIND population cycles has been a fundamental issue in ecology for decades (Krebs et al., 1995). Although a large body of literature exists on the subject of these fluctuations, many writers have conflicting views on the mechanisms behind the population changes (Krebs et al., 1995). There is no single cause of population fluctuations, and often the key factors are specific to a particular species or system. In the case of small mammals, cyclicity has been explained by three types of models: 1) top-down, 2) bottom-up, and 3) social interaction models (Krebs, 2011). In top-down models, the predators control the system through both direct and potentially indirect predation effects. In bottom-up models, the key limiting factor is food: as the food resources of a species decline, so does its population density. Finally, in models based on social interactions, it is behaviors of the individuals in the population at peak densities, such as territoriality and infanticide, that cause the cyclical trends (Krebs, 2011).

The snowshoe hare (Lepus americanus) is a keystone species in the boreal forest because it affects the demography and population dynamics of many other species in the ecosystem (Boutin et al., 1995). Throughout Canada and Alaska, hare abundance fluctuates regularly over periods of 9 to 11 years (Krebs et al., 2001). Hare population dynamics have a strong impact on specialist hare predators, such as lynx (Lynx canadensis), which fluctuate in response to hare abundance with a 1-2 year lag in their own cycle (Ward and Krebs, 1985; Stenseth et al., 1997). The numerous studies conducted since the snowshoe hare-lynx cycle was first described have improved our understanding of the mechanisms behind it. However, there are still unanswered questions on the role of food in the population fluctuations of both hare and lynx.

\section{Food Limitation in Showshoe Hares}

For snowshoe hares, predation has been identified as the key limiting factor, with food showing only limited, indirect effects (Krebs, 2011). However, in previous studies examining the causal mechanisms, food addition was administered on a large scale. This approach can be problematic for several reasons, mainly because increased immigration to the food-rich area by other hares can lead to an influx of predators. Additionally, individuals may have unequal access to the food, which could alter the food addition results (Newey et al., 2010). Individual-based food addition solves both of these problems and is therefore an optimal method for investigating the role of food in the snowshoe hare cycle and uncovering the mechanisms behind the fluctuating abundance of the species. Food limitation can lead to reduced foraging, causing decreased body condition and overall health, and ultimately leading to reduced survival (Murray, 2002; Hodges et al., 2006). Furthermore, we lack the knowledge of the physiological and next-generation effects of food limitation on species that we need to understand how food reduction may play an integral role in the population cycle.

\section{Food Effects on Canada Lynx}

Lynx populations fluctuate in synchrony with prey abundance, and individuals are greatly dependent on snowshoe hare numbers to ensure their survival (O’Donoghue et al., 1997). The hare cycle has many direct effects (demographic, ecological, and behavioural) on lynx populations; however, much remains unknown about the indirect effects of the cycle on lynx through changes in their stress axis and physiological state. One important aspect that has been overlooked in previous studies is that predators may become stressed when they eat prey that were stressed. Levels of cortisol (a key hormone released during a stress response) may increase in the bloodstream of a predator when it consumes food that already contains high concentrations of cortisol (i.e., a stressed prey). Theoretically, this increased cortisol concentration in the predator should cause all the effects that stress hormones normally do when they are produced by the animal itself (Dantzer et al., 2013). Although lynx seemingly should have their highest cortisol levels during the decline and low phase of the hare cycle when food limitation is a major threat to their survival (Brand and Keith, 1979), cortisol absorption from their prey would instead cause their cortisol levels to reflect those of hares and be highest during the peak and early decline of their prey (Boonstra and Singleton, 1993).

The primary objective of this project is to examine the effects of food limitation on the ecology and physiology of adult hares by examining specific aspects of hare demography, population dynamics, and physiological profile throughout the peak and decline phase of the cycle. As well, this project will determine the cross-generational effects on reproduction and offspring quality that result from nutritional stress. In addition, by applying similar physiological measurements and techniques to the lynx, the project will be able to assess the influence of increased cortisol in hares on lynx physiology, as well as what lynx experience throughout the cycle. 


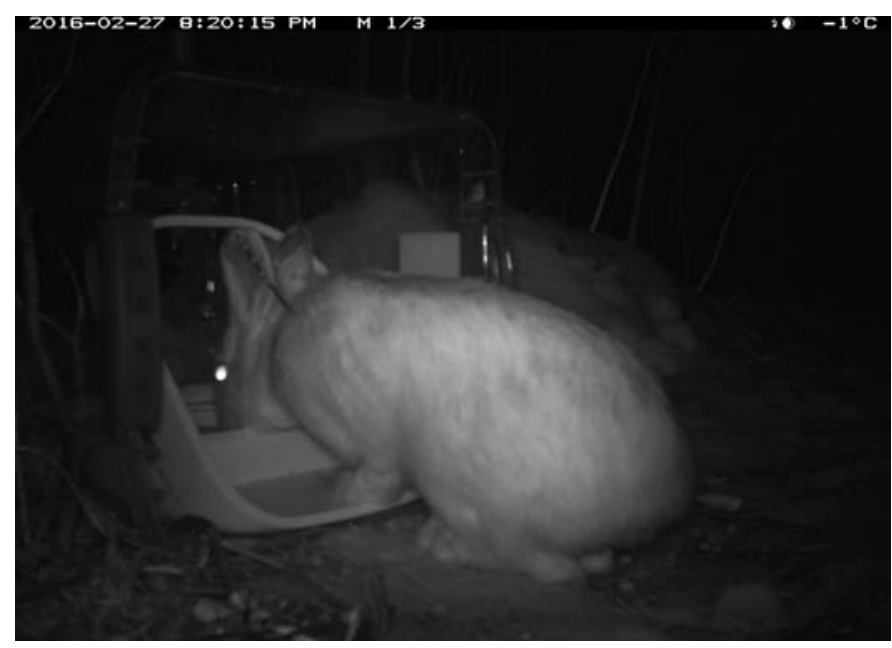

FIG 1. A snowshoe hare feeding at an automated feeder in the night. Trail cameras are set up at each feeder to monitor activity. Photo by Yasmine Majchrzak.

\section{METHODS}

\section{Food Limitation in Snowshoe Hares}

To accomplish this, I will radio-collar hares in the Kluane Lake region of the Yukon $\left(61^{\circ} \mathrm{N}, 138^{\circ} \mathrm{W}\right)$. Treatment hares will be individually fed throughout the winter, with known amounts of commercial rabbit chow from selective feeders (Fig. 1). These feeders allow controlled access to only a specified individual hare, ensuring the appropriate animals are supplemented. I will then monitor daily survival of each of these individuals using VHF telemetry to assess differential survival rates between control animals and food-supplemented animals (Fig. 2). In addition, I will take blood and fecal samples and measure a suite of physiological metrics to determine whether foodsupplemented hares experience less stress than control hares and whether they are in better condition. I will also determine whether this potential increased stress from food limitation results in maternal effects on the offspring (e.g., higher baseline cortisol, decreased body condition, smaller litters) by taking body measurements (weight, sex, and foot length) and tissue samples from juveniles at birth. If food limitation is a key mechanism in the hare cycle, I expect to see dramatically different responses between the two treatments. In particular, I predict that food-supplemented animals will show increased survival rates, decreased stress, less participation in risky behavior, larger litters, and higher quality offspring in terms of body condition and stress state. This portion of the project is being carried out with the help and support of the Arctic Institute of North America's Kluane Lake Research Station, Charles Krebs from the University of British Columbia, Murray Humphries from McGill University, and Dennis Murray from Trent University, as well as collaborations with $\mathrm{PhD}$ students from McGill University, Trent University, and the University of Toronto.

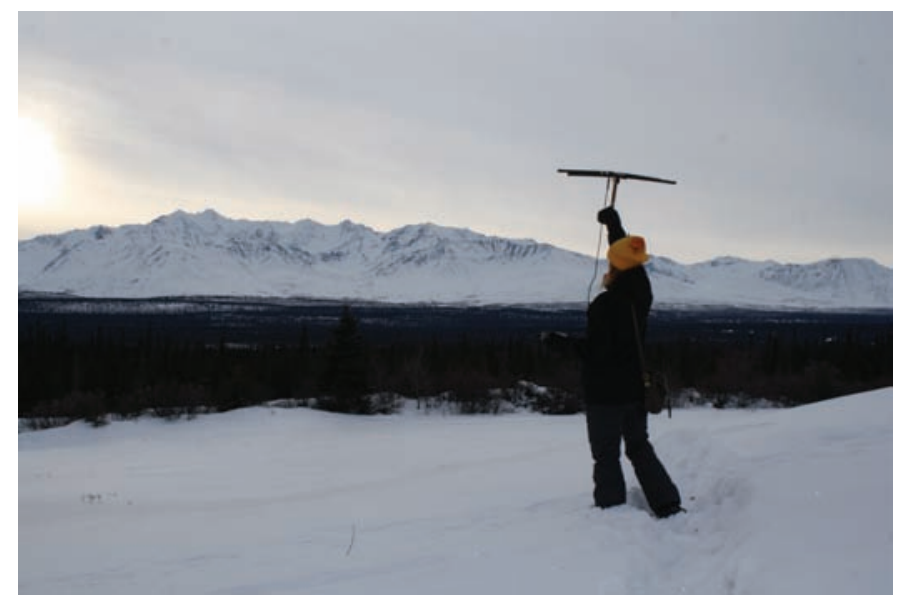

FIG. 2. Yasmine monitoring survival of snowshoe hares using VHF telemetry at our study site in the Kluane Lake area, Yukon. Photo by Michael Peers.

\section{Food Effects on Canada Lynx}

In order to characterize the physiological state of lynx during various points of the cycle, I am collecting lynx samples from the Yukon, where hares are at their peak and moving into the crash, and samples from Alaska, where hares and lynx are in the low phase of their cycle. My focus is mainly on areas where snowshoe hare abundance is currently being monitored, as I plan to collect fecal samples from hares in those areas in order to better understand the lynx environment and correlate the stress status of the two species. Sample collection will involve collecting blood, feces, and hair from both live lynx and lynx carcasses.

In order to gather samples from all these locations I have forged partnerships with students and community members across the Yukon and Alaska. In the Kluane Lake area of the Yukon, I have collaborated with graduate students from McGill University and Trent University, who are trapping and collaring lynx in the region. This collaboration provides the opportunity to collect more precise data and samples (i.e., blood, hair, feces, body measurements) on a smaller scale from lynx that are being regularly monitored and whose movements and behaviours are well known. In order to collect samples on a larger scale, I have established a program with the help of local and First Nations trappers to collect lynx carcasses in the Yukon from the Kluane Lake area, Mayo, Whitehorse, and the area south of Haines Junction (Fig. 3). Collaborating with trappers has allowed me to increase my geographical distribution of samples. I will use these carcasses to collect feces and hair and measure additional indicators of body condition. Yukon Environment is also collaborating in the lynx carcass collection program: they are supporting and assisting with the project, and many of the carcasses will be used for some of their conservation research programs. In Alaska, the hare-lynx cycle is currently at the low phase. This situation provides an opportunity to compare lynx experiencing the peak and decline phases in Yukon to lynx 


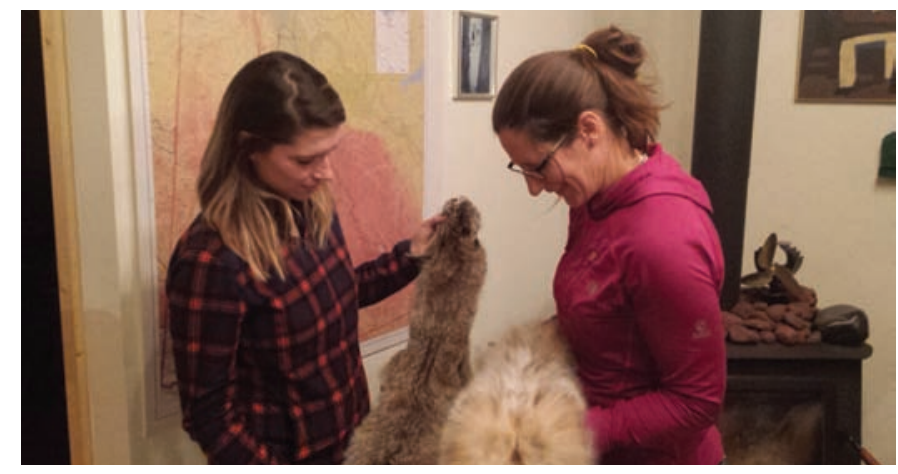

FIG. 3. Yasmine (left) discussing lynx trapping with local trapper Lisa Preto (right) from Haines Junction, Yukon. Photo by Michael Peers.

experiencing the low phase during the same time period in Alaska. To gather all necessary samples in Alaska, I am working with students from the University of Washington who are collecting both lynx and snowshoe hare feces in Denali National Park.

Blood samples will be taken from collared animals and used for a suite of physiological measurements: 1) cortisol, a measure of stress axis activity; 2) oxidative stress, an indicator of cellular degradation and susceptibility to pathological problems; 3) hematocrit, a measure of red blood cell production and an indicator of health; 4) the neutrophil-to-lymphocyte ratio, an indicator of immune function; and 5) thyroid hormone, an indicator of nutritional stress. These samples will allow us to investigate the physiological status of lynx during the peak and decline phases thoroughly on a small scale. We predict that if the lynx are in fact absorbing cortisol from hares, they will show increased cortisol and potentially decreased overall body condition during the peak of the hare cycle despite an abundant food supply.

Hair samples and other tissue samples will be taken from collared lynx as well as from carcasses donated by trappers and used for hormone analysis (cortisol and thyroid). The hair samples will provide information on the physiological status of the lynx over a longer time period. Since hormones are absorbed into the hair shaft only during growth (i.e., during seasonal molt) (Gow et al., 2010), hair hormone levels represent one to two months of the animal's life. Since the trapping season in Yukon runs from December to March, samples collected during that time will provide data for the fall, which is the time when lynx grow their winter fur (Gow et al., 2010; Russell et al., 2012).

Fecal samples collected from lynx across Alaska and Yukon will be used for hormone analysis to measure cortisol and thyroid. Fecal samples cannot provide the detailed information regarding the physiological state of an animal that can be gathered from blood samples; however, feces are valuable because they can easily be collected from a large geographical area and their collection is noninvasive. With a wide geographical spread and a large number of fecal samples from both hares and lynx, we will be able to determine whether lynx take up cortisol from their prey and what consequences this uptake may have for the predator's physiology.

\section{SIGNIFICANCE}

The lynx-hare cycle is an ideal system to examine the role of food in cyclic populations and the consequences that food limitation can have for future generations. Understanding what drives fluctuations in hare abundance is becoming ever more important because climate change has been shown to destabilize cyclic populations (Ims et al., 2008; Kausrad et al., 2008) and affect nutrient quality and growth of browse species (Shaw et al., 2002). The stability of the snowshoe hare cycle is also important for the local community because of the influence of snowshoe hares on other species, particularly predators in the ecosystem that are harvested each year by local trappers for economic value and to maintain tradition. Furthermore, the potential for stress hormone supplementation in predators through food is a critical omission in our current knowledge of predatorprey interactions and deserves attention. In general, we require a deeper understanding of what regulates populations and the mechanisms driving population cycles in order to predict their persistence into the future accurately and to develop science-based management and conservation programs. Overall, this study will show the importance of food resources at multiple trophic levels and the direct and indirect effects food has on the hare-lynx cycle.

\section{ACKNOWLEDGEMENTS}

I am very honoured to have received the 2016 Lorraine Allison Memorial Scholarship, and I thank the selection committee and the Arctic Institute of North America for this opportunity. I am very grateful for the support from my supervisors Dr. Stan Boutin (University of Alberta) and Dr. Rudy Boonstra (University of Toronto). I want to thank my bunny people, fellow graduate student Michael Peers, and all the technicians that have helped with the project; their hard work has made this intensive study possible. Thank you to Charles Krebs and Alice Kenney for their mentorship and encouragement. I also want to thank the lynx crew (Allyson Menzies, Emily Studd, Kevin Chan, Dennis Murray, and Murray Humphries) for letting me take samples from their lynx and making me a part of the team. Major thanks go to Kaija Klauder and Laura Prugh for assisting me with sample collection in Alaska, which has allowed me to expand the scope of my project tremendously and ask bigger questions.

I have many collaborators in the Yukon without whom the project would be impossible. Thank you to Tom Jung, Piia Kukka, Shawn Taylor, and Yukon Environment for supporting my project and providing a workspace and training for the carcass program. And finally, thank you to the Yukon Trappers Association: the carcass collection depends on the contributions of local and First 
Nations trappers, and I am very grateful for their willingness to contribute carcasses to the project.

Additional funding for this project came from an Alexander Graham Bell Canada Graduate Scholarship from the Natural Sciences and Engineering Research Council of Canada, a Northern Studies Training Program grant, a University of Alberta Northern Research Award, and a Queen Elizabeth II graduate scholarship. Thank you to all the entities that believed in and funded our work.

\section{REFERENCES}

Boonstra, R., and Singleton, G.R. 1993. Population declines in the snowshoe hare and the role of stress. General and Comparative Endocrinology 91(2):126-143. http://dx.doi.org/10.1006/gcen.1993.1113

Boutin, S., Krebs, C.J., Boonstra, R., Dale, M.R.T., Hannon, S.J., Martin, K., Sinclair, A.R.E., et al. 1995. Population changes of the vertebrate community during a snowshoe hare cycle in Canada's boreal forest. Oikos 74(1):69-80. http://dx.doi.org/10.2307/3545676

Brand, C.J., and Keith, L.B. 1979. Lynx demography during a snowshoe hare decline in Alberta. The Journal of Wildlife Management 43(4):827-849.

http://dx.doi.org/10.2307/3808267

Dantzer, B., Newman, A.E.M., Boonstra, R., Palme, R., Boutin, S., Humphries, M.M., and McAdam, A.G. 2013. Density triggers maternal hormones that increase adaptive offspring growth in a wild mammal. Science 340(6137):1215-1217. http://dx.doi.org/10.1126/science.1235765

Gow, R., Thomson, S., Rieder, M., Van Uum, S., and Koren, G. 2010. An assessment of cortisol analysis in hair and its clinical applications. Forensic Science International 196(1-3):32-37. http://dx.doi.org/10.1016/j.forsciint.2009.12.040

Hodges, K.E., Boonstra, R., and Krebs, C.J. 2006. Overwinter mass loss of snowshoe hares in the Yukon: Starvation stress, adaptation or artifact? Journal of Animal Ecology 75:1 - 13 . http://dx.doi.org/10.1111/j.1365-2656.2005.01018.x

Ims, R.A., Henden, J.-A., and Killengreen, S.T. 2008. Collapsing population cycles. Trends in Ecology \& Evolution 23(2):79-86. http://dx.doi.org/10.1016/j.tree.2007.10.010

Kausrud, K.L., Mysterud, A., Steen, H., Vik, J.O., Østbye, E., Cazelles, B., Framstad, E., et al. 2008. Linking climate change to lemming cycles. Nature 456:93-97. http://dx.doi.org/10.1038/nature 07442

Krebs, C.J. 2011. Of lemmings and snowshoe hares: The ecology of northern Canada. Proceedings of the Royal Society B 278(1705):481-489.

http://dx.doi.org/10.1098/rspb.2010.1992
Krebs, C.J., Boutin, S., Boonstra, R., Sinclair, A.R.E., Smith, J.N.M., Dale, M.R.T., Martin, K., and Turkington, R. 1995. Impact of food and predation on the snowshoe hare cycle. Science 269(5227):1112-1115.

http://dx.doi.org/10.1126/science.269.5227.1112

Krebs, C.J., Boonstra, R., Boutin, S., and Sinclair, A.R.E. 2001. What drives the 10-year cycle of snowshoe hares. Bioscience 51(1):25-35.

http://dx.doi.org/10.1641/0006-3568(2001)051[0025:WDTYCO ]2.0.CO;2

Murray, D.L. 2002. Differential body condition and vulnerability to predation in snowshoe hares. Journal of Animal Ecology 71(4):614-625.

http://dx.doi.org/10.1046/j.1365-2656.2002.00632.x

Newey, S., Allison, P., Thirgood, S., Smith, A.A., and Graham, I.M. 2010. Population and individual level effects of overwinter supplementary feeding mountain hares. Journal of Zoology 282(3):214-220. http://dx.doi.org/10.1111/j.1469-7998.2010.00728.x

O’Donoghue, M., Boutin, S., Krebs, C.J., and Hofer, E.J. 1997. Numerical responses of coyotes and lynx to the snowshoe hare cycle. Oikos 80(1):150-162.

http://dx.doi.org/10.2307/3546526

Russell, E., Koren, G., Rieder, M., and Van Uum, S. 2012. Hair cortisol as a biological marker of chronic stress: Current status, future directions and unanswered questions. Psychoneuroendocrinology 37(5):589-601.

http://dx.doi.org/10.1016/j.psyneuen.2011.09.009

Shaw, M.R., Zavaleta, E.S., Chiariello, N.R., Cleland, E.E., Mooney, H.A., and Field, C.B. 2002. Grassland responses to global environmental changes suppressed by elevated $\mathrm{CO}_{2}$. Science 298(5600):1987-1990.

http://dx.doi.org/10.1126/science.1075312

Stenseth, N.C., Falck, W., Bjørnstad, O.N., and Krebs, C.J. 1997. Population regulation in snowshoe hare and Canadian lynx: Asymmetric food web configurations between hare and lynx. Proceedings of the National Academy of Sciences 94(10):5147-5152. http://dx.doi.org/10.1073/pnas.94.10.5147

Ward, R.M.P., and Krebs, C.J. 1985. Behavioural responses of lynx to declining snowshoe hare abundance. Canadian Journal of Zoology 63(12):2817-2824. http://dx.doi.org/10.1139/z85-421

Yasmine Majchrzak is the 2016 recipient of the Lorraine Allison Scholarship. Yasmine is currently a doctoral student in the Department of Biological Sciences, University of Alberta. E-mail:majchrza@ualberta.ca 